\title{
The Role of International Financial Institutions in Protecting the Vulnerable During Pandemics: Focus on World Bank in Developing Economies
}

\author{
Francis Kofi Korankye-Sakyi \\ University of Cape Coast
}

\begin{abstract}
This article assesses the position of International Financial Institutions (IFIs) ${ }^{1}$ such the World Bank in times of global crises. It finds out that during such times, international aid to thriving economies are not difficult to mobilise but without deliberate effort to trace the accountability of such funds. This article argued that law is central to advancing the plight of the vulnerable in society and the World Bank must direct aid to the legal structures and institutions in order to be positioned to assist the vulnerable to fight through the COVID-19 pandemic era. It recommends that the World Bank must follow up with enhancing and equipping legal structures of developing countries accessing any fund from it to ensure that such resources are channeled into the right economic sectors and that countries are deterred from laundering, misdirecting and misuse of funds.
\end{abstract}

Keywords: International Financial Institutions, World Bank, COVID-19 pandemic, the vulnerable, legal, developing countries

\section{INTRODUCTION}

The importance of law in development discourse as captured under Sustainable Development Goal 16 is a critical factor in establishing and maintaining the rule of law by empowering the most vulnerable persons and groups in society to exercise their fundamental human rights against unfettered legal regimes and political leadership, especially in times of global crises.

\section{THE WORLD BANK, JUSTICE AND EXPECTATIONS DURING PANDEMICS}

The nexus between access to justice and the fostering of a healthy business environment, economic growth, access to public services for the poor, including the curbing of corruption and curtailing the abuse of power is well noted and must reflect on discussions in this period of the COVID-19 pandemic. In the era of crises, institutions emerge as products of deep thinking and serve the long-term interest of international peace and development. For instance, the Bretton Woods institutions comprising the International Monetary Fund (IMF) and the International Bank for Reconstruction and Development (IBRD) were creations after World War II in 1944. In this light, the invitation to these international bodies to rescue developing economies in this unhealthy time of COVID-19 is, therefore, a legitimate expectation. From 1959 to 1991, multinational development banks which constitute part of the International Financial Institutions (IFIs) emerged as a result of the difficulties of the development paradigms of the times and have continued to execute programmes and projects within such expectations. This article takes a look at the role of the World 
Bank in building the judicial capacities of developing economies during this pandemic and advocates for support for a stronger monitoring and regulatory mechanisms in the application of these funds to ameliorate the sufferings of the masses for whom these funds are intended to benefit.

During this pandemic, issues that are coming to the fore strongly include access to justice by the vulnerable in the face of new enactments on restrictions and controls, financial management and economic policies, debts cancellations and economic bailouts as well as money laundering. Many developing countries have qualified and accessed bailout packages from internal and external sources, including those from the World Bank. There is a need for a focus on these financial supports and its management by governments to avoid laundering and mismanagement.

The World Bank as an IFI and its allies have mandates which include reconstruction and development; economic development; poverty alleviation; assistance in transition; and support for the balance of payment. The bank has developed a strategy focusing on the ambitious goals of ending extreme poverty and promoting shared prosperity among the citizens of member states.

The scope of law and development in economic development discussions focuses on formal institutions; discussions on how contracts can be enforced; the protection of property rights; and how the judiciary can be strengthened as an independent body and equipped to protect investors and improve economic growth in developing countries. The fact that the integration of the rule of law into development planning has always inured mostly to the benefit of the masses cannot be wrong as it focuses on the impact of international and domestic legal arrangements in countries on economic development and social progress. In the broader context, the rule of law must not just be limited to elements such as the transparency and accountability of the law, the right to a fair trial, upholding human rights and judicial independence but should make space for discussions on how lawyers are involved in advocacy, law reform, drafting of new legislation, legal education and in providing legal assistance and representation to the vulnerable in perverted times. There is, therefore, every reason for the IFIs' to reinforce their objective on law and development in such dispensation by directing sponsorship of activities that strengthen institutions with oversight responsibilities on the usage of funds advanced to countries to cushion the plight of their citizens.

The World Bank has over the years, in line with its mandates financed projects on law and development across the globe at different times. In the scheme of its affairs, institutions mandated to execute justice are vital to the achievement of its goals, such as to alleviate poverty and promote shared prosperity. The bank's work on justice focuses on building accessible, efficient and fair justice institutions that are pivotal to the sustainable reduction of poverty and increasing shared prosperity. It is estimated that, over the last two and a half decades, it has worked on about 800 justice and development projects around the globe. In this sense, the bank adopts a multidisciplinary approach when dealing with justice and development, leveraging on a wide network of experts, including judges, lawyers, economists, architects and social scientists, as well as specialists in the management of justice sector human resources, finance, infrastructure, data and Information, Communication and Technology.

\section{A FOCUS ON THE WOLRD BANK AND THE LAW IN PERSPECTIVE}

The key areas of intervention by the bank in law and development projects are discussed:

1. Support of justice institutions through targeted interventions that improve the specialist functions of the justice system, as well as its management, governance and oversight. This role must inform key decisions on the immediate and ultimate interventions purposed for anchoring developing economies in this critical time. Intervention must not only focus on doling out fiscal support but on safeguarding the channels of utilisation and accountability for its usage. In this respect, the support or developing both the hard and soft dimensions of the law must be pursued by the bank.

2. Legal empowerment, through the protection and proactive outreach to women, the poor and marginalised groups to understand and navigate their legal problems. This article emphasises that the only way to measure the impact of any intervention of the role in (1) above is to assess how it inures to the vulnerable persons and groups of society by holding governments 
accountable through an efficient legal regime; hence the call for the World Bank's support to focus on law and development in this crisis.

3. Justice in sectors through the strengthening of the regulatory frameworks and institutions of all those sectors critical for the achievement of broader development objectives. During this period attention on the financial sector transactions among states actors and the private sector; and its potential abuses and crime-related matters must not be overlooked. Support for the development and enhancement of the judicial order must be an investment worth considering by the bank. Grave issues of political graft, money laundering and official embezzlement of state resources emerge as critical issues in the broader development discourse.

4. Development of analytics and diagnostics to inform policy, promote dialogue among stakeholders and better target reforms. This is a technical role which seeks attention on nurturing specialisation on aspects of the law and development dynamics to meet specific targets at a time. I contend that the specific matter of the COVID-19 pandemic lends itself to such a focus. To this end, an investment to equip the judiciary to be savvy in the analytical and diagnostic models of the law would be appropriate.

The rule of law is fundamental to all economic activities and economic development and must not be lost or suffer any attack for any reason, especially in the period of this pandemic. Property and contract rights are the fundamental building blocks of market economies and must be secured as a necessity even in this crisis and beyond. One benefit for this intervention is that a well-established legal milieu for enforcing contracts assures business players that contracting parties including the states will comply with their obligations to keep economic activities on a sustainable path.

\section{CONCLUSION}

In conclusion, it is emphasised that a global pandemic such as COVID-19 poses a great risk to investors who will therefore demand absolute security from abuses of governments and private crimes before venturing into any market. Under secured legal environment, such businesses are assured of the benefits of their efforts in terms of time and cost. So far, the World Bank has played a major role and given general support to advance law and development projects in various stakeholder countries. What is recommended is for the bank to follow up with enhancing and equipping legal structures of developing countries accessing any fund from it to ensure that such resources are channeled into the right economic sectors and that countries are deterred from laundering, misdirecting and misuse of funds.

\section{ENDNOTE}

1. They comprise of the World Bank (the International Bank for Reconstruction and Development (IBRD) and the concessional lending window, the International Development Association (IDA), and the four major regional development banks; the African Development Bank (AfDB); the Asian Development Bank (ADB); the European Bank for Reconstruction and Development (EBRD); and the Inter-American Development Bank (IADB) belonging to Africa, Asia and the Pacific, Europe, and Latin America respectively. IBRD was the first international development organization established in 1944, followed by IADB (in 1959), IDA (in 1960), AfDB (in 1964), ADB (in 1966), and EBRD (in 1991).

\section{REFERENCES}

Government of Canada. (n.d.). Overview of International Financial Institutions (IFIs). Retrieved April 3, 2020, from https://www.tradecommissioner.gc.ca/development-developpement/mdboverviewbmd-apercu.aspx?lang=eng

Imposition of Restriction Act, 2020 (Act 1012), Ghana.

Nanwani, S. (2016). Multilateral development banks and law and development projects in Asia: Experiences and directions. IIUMLJ, 24(1), 1-37. 
The Law and Development Institute. (n.d.). Retrieved May 18, 2020, from https://lawanddevelopment.net/

The World Bank. (n.d.). Global Economy on Track for Strong but Uneven Growth as COVID-19 Still Weighs. Retrieved April 15, 2020, from https://www.worldbank.org/en/home

The World Bank. (n.d.). Justice and Development. Retrieved May 18, 2020, from https://www.worldbank.org/en/topic/governance/brief/justice-rights-and-public-safety

United Nations. (n.d.). Legal Empowerment of the poor and eradication of poverty: Report of the Secretary-General. Retrieved May 23, 2020, from

https:/www.un.org/esa/socdev/documents/reports/Legal\%20empowerment $\% 20$ of $\% 20$ the $\% 20$ poo r.pdf

United Nations. (n.d.). The 17 Goal | Sustainable Developments. Retrieved January 23, 2020, from https://sdgs.un.org/goals.

World Health Organization. (2020). Rolling updates on coronavirus disease (COVID-19). Retrieved April 3, 2021, from https://www.who.int/emergencies/diseases/novel-coronavirus-2019/events-astheyhappen 